\title{
Structural damage in rheumatoid arthritis, psoriatic arthritis, and ankylosing spondylitis: traditional views, novel insights gained from TNF blockade, and concepts for the future
}

\author{
Georg Schett ${ }^{1 *}$, Laura C Coates², Zoe R Ash³, Stefanie Finzel' and Phillip G Conaghan ${ }^{4}$
}

\begin{abstract}
Structural changes of bone and cartilage are a hallmark of inflammatory joint diseases such as rheumatoid arthritis (RA), psoriatic arthritis (PsA), and ankylosing spondylitis (AS). Despite certain similarities - in particular, inflammation as the driving force for structural changes - the three major inflammatory joint diseases show considerably different pathologies. Whereas RA primarily results in bone and cartilage resorption, PsA combines destructive elements with anabolic bone responses, and AS is the prototype of a hyper-responsive joint disease associated with substantial bone and cartilage apposition. In the present review we summarize the clinical picture and pathophysiologic processes of bone and cartilage damage in RA, PsA, and AS, we describe the key insights obtained from the introduction of TNF blockade, and we discuss the future challenges and frontiers of structural damage in arthritis.
\end{abstract}

\section{Introduction}

Structural changes of cartilage and bone resulting from arthritis were recognized in the mid-nineteenth century: witness Baker's description of bone cysts as a protective mechanism for the joint [1]. These cysts were considered pressure-regulated escape mechanisms for the inflamed synovium into the marrow space [2]. Damage of the periarticular bone and the articular cartilage are now known to be hallmarks of arthritis, symbolizing the destructive potential of chronic inflammation. A deeper

*Correspondence: Georg.schett@uk-erlangen.de

'Department of Internal Medicine 3, Institute for Clinical Immunology, University of Erlangen-Nuremberg, Krankenhausstrasse 12, 91054 Erlangen, Germany Full list of author information is available at the end of the article insight into the mechanism of structural changes triggered by chronic joint diseases such as rheumatoid arthritis (RA), psoriatic arthritis (PsA), and ankylosing spondylitis (AS) is essential for developing therapies that can arrest, prevent, and even reverse bone and cartilage changes. More specific interventions to treat inflammation in arthritis, for example monoclonal antibodies and soluble receptors, have added considerably to our knowledge of arthritic structural damage. In particular, the blockade of TNF has shown that effective anti-inflammatory therapy can preserve joint structure, which is critical to maintaining joint function.

RA, PsA, and AS differ substantially in their patterns of bone and cartilage damage. These differences are at least partly based on the variable capability to form new bone, which may reflect a skeletal response to inflammation. Goals and strategies to prevent and treat structural damage should therefore also differ. In the present article, we summarize the mechanistic concepts of structural damage in these three major joint diseases, we review the achievements of TNF blockers - in particular, their contribution to understanding structural damage - and we discuss unanswered questions and future frontiers in the management of bone and cartilage damage in RA, PsA, and AS.

\section{Rheumatoid arthritis}

\section{Original thoughts on structural damage in RA}

RA is the prototype of a destructive arthritis. The disease directly leads to joint damage, with only a few signs of repair. Traditionally, structural damage in RA has been identified using conventional radiography to detect cortical bone erosions, joint space narrowing, and periarticular osteoporosis. Imaging has shown unequivocally that there is a net loss of cartilage and bone in patients with RA. In particular, the presence of bone erosions has emerged as an indicator of irreversible damage resulting from a continuous inflammatory attack of the synovial membrane on bone. Synovitis is of pivotal importance for 
bone and cartilage damage in RA. Both the severity of inflammation - whether measured by C-reactive protein, the number of swollen joints, or the duration of morning stiffness - and the duration of inflammation have therefore emerged as important predictors of structural damage in RA [3,4]. Autoantibodies such as rheumatoid factor and anti-citrullinated protein antibodies, and - in close connection to anti-citrullinated protein antibodies - the presence of the shared epitope in the HLA-DRB1 region, also predict the risk for bone erosions, which is probably related to a close association between autoantibodies and the chronicity of arthritis [5,6]. Molecularly, the tight interaction between inflammation and bone/cartilage loss in RA is explained by the production of enzymes such as aggrecanases and matrix metalloproteinases, which degrade articular cartilage and bone as well as molecules that support the differentiation of osteoclasts [7].

Bone and cartilage loss has traditionally been a main diagnostic, monitoring, and outcome parameter in patients with RA in both clinical trials and routine clinical practice. Bone and cartilage damage is rapid and dynamic after disease onset and affects the majority of RA patients within the first year [8]. The severity of bone and cartilage damage in RA is closely related to physical function in RA patients, suggesting that structural damage indeed impairs physical function [9-11]. Finally, effective control of inflammation by conventional disease-modifying antirheumatic drugs (DMARDs) or combination therapies of DMARDs and glucocorticoids retards structural damage in RA. Structure-sparing effects have been documented for methotrexate (MTX), sulfasalazine, and leflunomide individually and in combination [12-15]. It is not clear, however, whether MTX, sulfasalazine, leflunomide, and hydroxychloroquine directly affect bone and cartilage damage, or indirectly benefit joints by reducing inflammation.

\section{Novel insights gained from use of TNF blockers in RA}

The introduction of TNF blockers as a therapeutic option in RA has challenged our view not only of synovitis but also of progression of structural damage. One of the most consistent effects of TNF-blocking agents in RA patients is a profound and sustained inhibition of bone erosion. In fact, all five TNF blockers approved for the therapy of RA strongly retard or even arrest structural damage [16-24]. This strong structure-preserving effect is partially due to profound and rapid control of inflammation. Also apparent, however, is that anti-resorptive effects may occur despite a lack of clinical response to a TNF blocker [24]. TNF-blocking agents thus combine a strong antiinflammatory potential, which controls synovitis, with direct protection of bone and cartilage (Table 1).

In this context it is noteworthy that TNF is an important inducer of osteoclast formation and thus is a key molecular link between inflammation and bone damage [7]. Addition of TNF to monocyte cultures challenged with macrophage colony-stimulating factor and receptor activator of NF- $\mathrm{kB}$ ligand (molecules that activate osteoclasts, which are the cells involved in bone resorption) enhances the formation of osteoclasts, and overexpression of TNF in mice entails increased formation of osteoclasts resulting in systemic bone loss as well as local bone erosions [25-27]. With respect to cartilage damage, TNF also is an inducer of matrix enzymes such as aggrecanases and metalloproteinases, particularly MMP-1, MMP-2, and MMP-3, which are produced by synovial fibroblasts, neutrophils, and chondrocytes and degrade the cartilage matrix. A specific protective effect of TNF blockade on articular cartilage is therefore conceivable; current evidence is circumstantial, however, and is not backed by sufficient data. Direct assessment of the cartilage of small peripheral joints is still technically challenging and, to date, TNF blockers have shown little if any effect on the cartilage [28].

\section{Future needs and unanswered questions in RA}

TNF-blocking agents have undoubtedly enriched our therapeutic options for blocking structural damage in RA. Nonetheless, several aspects remain enigmatic. The lack of adequate spontaneous joint repair and better strategies to induce joint repair will be a central field of future basic and clinical research. Indeed, any potential for erosion self-healing is still poorly characterized. Examination of sequential radiographs from clinical studies suggest that individual lesions can improve, especially when there is no or reduced swelling in the joint [29]. Other studies indicate that joint repair and erosion healing is rare despite effective therapy with TNF inhibitors [30]. More detailed imaging techniques such as ultrasound, magnetic resonance imaging (MRI), and computed tomography may provide better information in the future. Refilling bone erosions might be an important clinical goal, if the technique could restore ligament and enthesial function. If such repair proves possible, it must be followed by an assessment of joint function.

Future frontiers in RA also will include the interaction between inflammation and structural progression. With improved treatment options and tighter control of inflammation, more patients will have low disease activity or will be in remission. Even patients who are considered to be in clinical remission, however, can progress in structural damage [31-33]. How much residual synovitis is necessary to allow structural progression is not yet clear. Even subclinical synovitis may suffice to trigger a progression of cartilage and bone damage followed by a decrease in joint function. Improved detection of synovitis with ultrasound and MRI may allow a better understanding of the effect of subclinical synovitis on joint structure [34-38]. 
Table 1. Key studies of TNF-blocker therapy in rheumatoid arthritis, 52-week follow-up

\begin{tabular}{|c|c|c|c|c|}
\hline Therapy & Disease stage & Reference & Primary outcome & Radiologic outcome \\
\hline Infliximab & RA & Smolen and colleagues [16] & ACR20 & Modified TSS \\
\hline Infliximab & Early RA & Smolen and colleagues [17] & ACR20 & Modified TSS \\
\hline Etanercept & Early RA & Bathon and colleagues [18] & ACR20 & TSS \\
\hline Etanercept & RA & Klareskog and colleagues [19] & ACR20 & Modified TSS \\
\hline Etanercept & Early RA & Kekow and colleagues [20] & ACR20 & Modified TSS \\
\hline Adalimumab & Early RA & Breedveld and colleagues [21] & ACR50 & Modified TSS \\
\hline Adalimumab & RA & Keystone and colleagues [22] & ACR20 & Modified TSS \\
\hline Golimumab & RA & Kremer and colleagues [23] & ACR50 & Modified TSS \\
\hline Certolizumab & RA & Keystone and colleagues [24] & ACR20 & Modified TSS \\
\hline
\end{tabular}

ACR20/50, American College of Rheumatology 20\%/50\% improvement; RA, rheumatoid arthritis; TSS, total Sharp score.

\section{Psoriatic arthritis}

\section{Original thoughts on structural damage in PsA}

For a long time, PsA was not recognized as a specific entity but rather was considered a subtype of RA that occurred in combination with skin psoriasis. Even after formal recognition, PsA was considered to be a mild disease with a benign course. Research in PsA has long lagged behind RA research in terms of diagnosis, prognosis, and treatment. The diagnostic criteria of Moll and Wright, although not based on patient-derived data and omitting key features of PsA such as nail disease and dactylitis, were widely used [39]. These criteria did not mitigate difficulties classifying study patients, and therefore research remained limited. The Classification Criteria for Psoriatic Arthritis now provide sensitive and specific classifications for PsA [40]. Research is still limited in early disease, however, as the Classification Criteria for Psoriatic Arthritis were built on data from patients with long-standing disease.

PsA patients suffer significant joint damage and disability over time. In accordance with RA, PsA is an erosive disease leading to the resorption of cortical bone. In addition, however, PsA shows morphological features discordant with RA; that is, the formation of bony spurs along the insertion sites of the entheses (enthesiophytes) [41]. Depending on the scoring system used, the damage and disability in PsA is less pronounced than in RA [42] or is equal to RA [43] with equivalent disease duration. Patients with RA and patients with PsA have similar functional and quality-of-life impairment [42].

Data from longitudinal cohort studies have helped identify severe disease with poor structural outcome. High inflammatory activity and joint damage at the time of presentation are considered the most important predictors of future clinical and radiologic joint damage $[44,45]$. For instance, a high erythrocyte sedimentation rate at baseline and the presence of joint swelling suggest a poor prognosis with respect to structural outcome $[44,46]$. Moreover, patients with axial disease have more severe peripheral joint disease [47].
Previously, therapies for PsA were borrowed from RA, often without any specific studies to assess their effectiveness in this different condition. There is a surprising lack of randomized controlled trials evaluating the impact of DMARD therapy on PsA. Observational studies of patients receiving traditional DMARD therapy, however, have shown little control of structural damage. Observational controlled studies with sulfasalazine and gold have shown no reduction in long-term joint damage $[48,49]$. An observational cohort study of 23 patients who received 2-year MTX therapy concluded that MTX treatment did not reduce radiologic progression compared with matched controls [50]. However, a more recent analysis of the same cohort - but without controls - has suggested otherwise [51]. Chandran and colleagues found that since the mid-1990s MTX had been prescribed earlier and in higher doses, resulting in a significant decline in actively inflamed joint count and psoriasis, and some decrease in progression of radiologic joint damage [51]. There is no direct evidence, however, showing that DMARD therapy affects joint damage.

\section{Novel insights gained from use of TNF blockers in PsA}

TNF blockers have provided the first evidence-based treatment for PsA with proven effects on arthritis, skin disease, enthesitis, dactylitis, and spinal disease. These agents are highly effective in PsA, and they are the first with proven efficacy at reducing both active joint inflammation and radiographic damage in randomized controlled trials of PsA [52-56] (Table 2). The vast majority of PsA patients treated with TNF blockers showed no worsening in radiographic damage scores [52,55-58]. Since the scoring systems used for the assessment of radiographic damage of PsA are the same as those used for RA, however, our knowledge about TNF-blocker effects on structural damage are confined to the erosive component of the disease, and it is unclear whether these agents also affect enthesiophyte formation. 
Table 2. Key studies of TNF-blocker therapy in psoriatic arthritis

\begin{tabular}{|c|c|c|c|c|c|c|c|c|c|c|c|c|c|c|}
\hline \multirow[b]{3}{*}{ Therapy } & \multirow[b]{3}{*}{ Published study } & \multirow{3}{*}{$\begin{array}{l}\text { Primary } \\
\text { outcome }\end{array}$} & \multirow{3}{*}{$\begin{array}{l}\text { Radiologic } \\
\text { outcomes }\end{array}$} & \multicolumn{11}{|c|}{ Outcomes reported } \\
\hline & & & & \multirow[b]{2}{*}{ Joint } & \multirow[b]{2}{*}{ Skin } & \multirow{2}{*}{ Nail } & Dactylitis & \multirow{2}{*}{\multicolumn{2}{|c|}{ Function }} & \multirow[b]{2}{*}{ QoL } & \multirow[b]{2}{*}{ Pain } & \multirow[b]{2}{*}{ EMS } & \multirow[b]{2}{*}{ Fatigue } & \multirow{2}{*}{$\begin{array}{l}\text { CRP/ } \\
\text { ESR }\end{array}$} \\
\hline & & & & & & & & & & & & & & \\
\hline Infliximab & $\begin{array}{l}\text { Antoni and } \\
\text { colleagues [59], } \\
\text { Kavanaugh and } \\
\text { colleagues [52] }\end{array}$ & $\begin{array}{l}\text { ACR20 at } \\
\text { week } 16\end{array}$ & $\begin{array}{l}\text { mvdH-SS at } \\
\text { week } 50\end{array}$ & $x$ & $x$ & & $x$ & $x$ & $x$ & & $x$ & & & $x$ \\
\hline Infliximab & $\begin{array}{l}\text { Antoni and } \\
\text { colleagues [60], } \\
\text { van der Heijde and } \\
\text { colleagues [56] }\end{array}$ & $\begin{array}{l}\text { ACR20 at } \\
\text { week } 14\end{array}$ & $\begin{array}{c}\text { mvdH-SS at } \\
\text { weeks } 24 \text { and } 54\end{array}$ & $x$ & $x$ & & $x$ & $x$ & $x$ & & $x$ & $x$ & & $x$ \\
\hline Etanercept & $\begin{array}{l}\text { Mease and } \\
\text { colleagues [61] }\end{array}$ & $\begin{array}{l}\text { PsARC at } \\
\text { week } 12\end{array}$ & NA & $x$ & $x$ & & & & $x$ & & $x$ & & & $x$ \\
\hline Etanercept & $\begin{array}{l}\text { Mease and } \\
\text { colleagues [58] }\end{array}$ & $\begin{array}{l}\text { ACR20 at } \\
\text { week } 12\end{array}$ & $\begin{array}{c}\text { mTSS at } \\
\text { months } 6 \text { and } 12\end{array}$ & $x$ & $x$ & & & & $x$ & & $x$ & & & $x$ \\
\hline Adalimumab & $\begin{array}{l}\text { Mease and } \\
\text { colleagues [54] }\end{array}$ & $\begin{array}{l}\text { ACR20 at } \\
\text { week } 12\end{array}$ & $\begin{array}{l}\text { mTSS at } \\
\text { week } 24\end{array}$ & $x$ & $x$ & & $x$ & $x$ & $x$ & $x$ & & & $x$ & \\
\hline Golimumab & $\begin{array}{l}\text { Kavanaugh and } \\
\text { colleagues [62] }\end{array}$ & $\begin{array}{l}\text { ACR20 at } \\
\text { week } 14\end{array}$ & NA & $x$ & $x$ & $x$ & $x$ & $x$ & $x$ & & & & & \\
\hline
\end{tabular}

ACR20, American College of Rheumatology 20\% improvement; CRP/ESR, C-reactive protein/erythrocyte sedimentation rate, EMS, early morning stiffness; mvdH-SS, modified van der Heijde-Sharp score; mTSS, modified total Sharp score; NA, not available; PsARC, Psoriasis Arthritis Response Criteria; QoL, quality of life.

\section{Future needs and unanswered questions in PsA}

The next step in investigating structural damage in PsA is to search for evidence of a direct link between inflammation and joint damage. Imaging studies have elegantly demonstrated this link in RA, using a combination of MRI, ultrasound, and conventional radiography [63,64]. Such data, however, are currently unavailable in PsA. Also of interest is the link between inflammation and new bone formation, which is typical for PsA but is not encountered in RA.

As in RA, we must evaluate the use of anti-inflammatory therapies in PsA and investigate their ability to prevent long-term damage. If there is a direct link between inflammation and damage in PsA, then tight control of inflammation may arrest damage in PsA - as has been demonstrated in RA $[65,66]$. Does this also apply to enthesiophyte formation? The answer is unclear and at least doubtful, as the formation of bony spurs in AS is not influenced by TNF blockade. In this context it also will be important to define treatment targets based on either clinical outcomes or imaging. For instance, a new clinical measure for minimal disease activity encompassing remission and low disease activity has been developed, but needs further testing in prospective studies [67].

\section{Ankylosing spondylitis}

\section{Original thoughts on structural damage in AS}

Low back pain is the earliest clinical manifestation for AS and indicates inflammation in the sacroiliac joints and the spine, which can be identified by MRI [68]. Disease progression is characterized by ongoing back pain leading to skeletal changes in the sacroiliac joints, identifiable by plain radiography. The diagnosis of AS has long hinged upon evidence of structural damage; the modified New York criteria require the presence of radiographic sacroiliitis to give a definite diagnosis [69]. Studies have shown that it can take up to 10 years for these changes to become visible on plain radiographs [70], but radiographs are still widely used in established disease. Skeletal changes in the sacroiliac joints in AS are characterized by the concomitant presence of catabolic changes such as erosions as well as new bone formation leading to progressive ankylosis.

Spinal syndesmophytes are thought to appear at a later stage [71], although this hypothesis remains unclear. This concept is supported by two facts: patients in the preradiographic stages of AS can suffer just as much pain and stiffness as those already diagnosed [72]; and patients treated early with TNF blockers demonstrate a better response than those treated later in their disease course [73]. Treatment should be started in the early stages of the disease process, before irreversible structural damage has occurred; that is, before the modified New York criteria are fulfilled. With the new classification criteria of spondylarthritis it will be possible to start effective medication earlier, which may yield a considerable change of the disease course in the future.

Spinal structural changes in AS are quantified radiographically using the modified Stoke Ankylosing Spondylitis Spine Score, which grades the cervical and lumbar spine for the presence of erosions, squaring, sclerosis, syndesmophytes, and bony bridging at each site [74]. The 
Table 3. Key studies of TNF-blocker therapy in ankylosing spondylitis

\begin{tabular}{|c|c|c|c|c|c|c|c|c|c|c|c|}
\hline \multicolumn{12}{|c|}{ Outcomes reported } \\
\hline Therapy & Published study & $\begin{array}{l}\text { Primary } \\
\text { outcome }\end{array}$ & $\begin{array}{l}\text { Radiologic } \\
\text { outcome }\end{array}$ & $\begin{array}{l}\text { Follow- } \\
\text { up }\end{array}$ & BASDAI & BASFI & BASMI & QoL & EMS & Fatigue & $\begin{array}{l}\text { CRP/ } \\
\text { ESR }\end{array}$ \\
\hline Infliximab & $\begin{array}{l}\text { Braun and colleagues } \\
\text { [96-100] }\end{array}$ & $\begin{array}{l}50 \% \text { improvement } \\
\text { in BASDAl at week } 12\end{array}$ & mSASSS & 5 years & $x$ & $x$ & $x$ & $x$ & $x$ & & $x$ \\
\hline Infliximab & $\begin{array}{l}\text { Marzo-Ortega and } \\
\text { colleagues [101] }\end{array}$ & $\begin{array}{c}\text { Change in BASDAl } \\
\text { at weeks } 4 \\
10,30\end{array}$ & $\begin{array}{c}\text { MRI } \\
\text { inflammatory } \\
\text { lesions }\end{array}$ & 30 weeks & $x$ & $x$ & & $x$ & $x$ & & $x$ \\
\hline Infliximab & $\begin{array}{l}\text { van der Heijde and } \\
\text { colleagues }[83,102]\end{array}$ & $\begin{array}{l}\text { ASAS } 20 \text { at } \\
\text { week } 24\end{array}$ & mSASSS & 8 years & $x$ & $x$ & $x$ & $x$ & $x$ & $x$ & $x$ \\
\hline Etanercept & $\begin{array}{l}\text { Davis and colleagues } \\
{[103-105], \text { van der Heijde }} \\
\text { and colleagues [84] }\end{array}$ & $\begin{array}{l}\text { ASAS } 20 \text { at } \\
\text { week } 12\end{array}$ & mSASSS & 16 years & $x$ & $x$ & $x$ & & $x$ & & $x$ \\
\hline Etanercept & $\begin{array}{l}\text { Calin and colleagues } \\
\text { [106], Dijkmans and } \\
\text { colleagues [107] }\end{array}$ & $\begin{array}{l}\text { ASAS } 20 \text { at } \\
\text { week } 12\end{array}$ & mSASSS & 8 years & $x$ & $x$ & $x$ & & $x$ & & $x$ \\
\hline Adalimumab & $\begin{array}{l}\text { van der Heijde and } \\
\text { colleagues [108] }\end{array}$ & $\begin{array}{l}\text { ASAS } 20 \text { at } \\
\text { week } 12\end{array}$ & NA & 24 weeks & $x$ & $x$ & $x$ & $x$ & $x$ & & $x$ \\
\hline Golimumab & $\begin{array}{l}\text { Inman and colleagues } \\
{[109]}\end{array}$ & $\begin{array}{l}\text { ASAS } 20 \text { at } \\
\text { week } 14\end{array}$ & NA & 24 weeks & $x$ & $x$ & $x$ & $x$ & $x$ & & $x$ \\
\hline
\end{tabular}

ASAS, Assessment of Spondyloarthritis International Society; BASDAI, Bath Ankylosing Spondylitis Disease Activity Index; BASFI, Bath Ankylosing Spondylitis Functional Index; BASMI, Bath Ankylosing Spondylitis Metrology Index; CRP/ESR, C-reactive protein/erythrocyte sedimentation rate; EMS, early morning stiffness; MRI, magnetic resonance imaging; mSASSS, modified Stoke Ankylosing Spondylitis Spine Score; NA, not applicable; QoL, quality of life.

inability, however, of the modified Stoke Ankylosing Spondylitis Spine Score to assess the thoracic spine [75], which is the most commonly involved area as shown on MRI studies [76], limits the score's sensitivity to assess change. Spoorenberg and colleagues have demonstrated that a minimum 2 years of follow-up is necessary to reliably detect radiographic change, meaning that studies assessing radiographic damage must be of significantly longer duration than similar studies in peripheral arthritis [77].

Traditionally, AS has been treated with regular physiotherapy and nonsteroidal anti-inflammatory drugs (NSAIDs). Indeed, the only evidence for a reduction in radiographic progression in patients with AS is from a trial of continuous versus on-demand treatment with NSAIDs. Patients on continuous NSAID therapy had significantly reduced radiographic progression compared with those who took the therapy only when serious symptoms were present [78]. Both groups experienced similar effects on symptoms, inflammation, and spinal mobility.

\section{Novel insights gained from use of TNF blockers in AS}

The advent of TNF inhibitors has greatly improved the treatment options for AS. They allow treatment of patients with severe disease who do not fully respond to NSAIDs. Three TNF blockers are licensed and approved worldwide, and a fourth blocker (golimumab) was recently approved. Criteria have been set by various regulatory bodies for their use $[79,80]$.
Similar efficacy has been found for all of the TNF blockers, although studies have consistently shown that patients relapse with cessation of therapy $[81,82]$ (Table 3). Despite the strong anti-inflammatory effect of TNF blockers in AS, these agents do not influence new bone formation in AS [83-85]. Only one small study showed reduced radiographic progression in AS patients treated with infliximab in comparison with a historical cohort, but these results have to be considered with caution as the baseline Bath Ankylosing Spondylitis Disease Activity Index score was different between the groups $[86,87]$.

This lack of a structure-sparing effect of TNF blockers in AS unravels the different pathophysiologic mechanisms underlying RA, PsA, and AS. RA is typically characterized by bone erosion, whereas the main structural outcome in AS is bony spur formation based on bone formation.

Radiographic damage at baseline is a major predictor of future radiographic progression; in particular, the presence of syndesmophytes or ankylosis [86,88]. MRIevident sacroiliitis and positivity for HLA-B27 have been shown to predict the development of radiographic sacroiliitis in patients with early inflammatory back pain at 8 -year follow-up, with a sensitivity and specificity of $77 \%$ each [89]. MRI has now been incorporated into the new Assessment of Spondyloarthritis International Society classification criteria for axial spondyloarthritis [90].

The relationship between inflammation and new bone formation in AS remains unclear. Recent MRI studies 
have shown that active corner inflammatory lesions (also known as Romanus lesions or bone edema) predict the development of syndesmophytes [91]. These studies also demonstrated formation of syndesmophytes at the exact location of resolved inflammatory lesions. One explanation is that there may be persistent mild inflammation not detected by MRI. The discovery that syndesmophytes were more likely to develop at the sites of resolved corner inflammatory lesions rather than those of persistent lesions, however, led to the TNF brake hypothesis. This hypothesis suggests that TNF triggers pathways leading to new bone formation, but that while there is active inflammation TNF suppresses new bone formation via dickkopf-1 (a regulator of joint remodeling) [92]. When patients are treated with TNF inhibitors, therefore, inflammation resolves, the brake is released, and tissue repair and new bone formation occur [91]. This process may account for radiographic progression in patients who appear to otherwise respond well to anti-TNF therapy. Evidence for uncoupling between inflammation and new bone formation is supported by a mouse model of spondyloarthritis, which showed no effect of etanercept on the severity and incidence of joint ankylosis [93].

An independent study of patients receiving anti-TNF agents found that an inflamed vertebral edge at baseline had a threefold increased risk to develop a syndesmophyte than a non-inflamed vertebral edge [94]. These results contrast with those of Maksymowych and colleagues [91]. MRI scans were performed only at baseline and 2 years, however, so it is possible that inflammation had occurred and resolved between scans. Bennett and colleagues described fatty Romanus lesions in the spine, which they suggest may be the postinflammatory phase between osteitis on MRI and sclerotic bone formation on radiographs [95].

\section{Future needs and unanswered questions in AS}

Despite the efficacy of TNF blockers for symptomatic control and improved quality of life in patients with AS, the lack of efficacy for radiographic progression is noteworthy. Longer studies may be needed, because the process linking inflammation and new bone formation is slow. Effective suppression of inflammation may thus still reduce radiographic progression.

Additional research is needed to analyze whether progression is due to persistent, low-grade inflammation or to the release of the TNF brake once inflammation is effectively treated. The answer to this question will guide future therapies. Perhaps a dual approach will be necessary: one therapy to treat inflammation and another to prevent new bone formation.

MRI has facilitated the study of early disease, and the treatment response of patients in the pre-radiographic stage may help determine whether suppression of inflammation can prevent early onset of structural damage. Since not all patients with MRI-evident sacroiliitis develop AS, however, treatment must be carefully targeted. Lastly, there is the issue of late presentation of AS patients to rheumatologists, which can be improved by the education of both doctors and patients.

\section{Abbreviations}

AS, ankylosing spondylitis; DMARD, disease-modifying antirheumatic drug; MMP, matrix metalloproteinase; MTX, methotrexate; MRI, magnetic resonance imaging; NF, nuclear factor; NSAID, nonsteroidal anti-inflammatory drug; PSA, psoriatic arthritis; RA, rheumatoid arthritis; TNF, tumor necrosis factor.

\section{Competing interests}

ZRA has received research grants from Schering-Plough Corporation, now Merck Sharp \& Dohme. PGC has received research grants from Pfizer, and has been a speaker for Merck \& Company, Inc. and AstraZeneca. The remaining authors declare that they have no competing interests.

\section{Acknowledgements}

Merck, Sharp \& Dohme Corporation (Whitehouse Station, NJ, USA) provided financial support for this article. Synergy Medical Education (Conshohocken PA, USA) assisted in the preparation of the manuscript.

This article is part of Arthritis Research \& Therapy Volume 13 Supplement 1: The evolution of anti-TNF therapy in rheumatic disease: experience, insights and advances. The full contents of the supplement are available online at http://arthritis-research.com/supplements/13/S1. Publication of this supplement is sponsored by Merck, Sharp \& Dohme Corporation, Whitehouse Station, New Jersey, USA.

\section{Author details}

'Department of Internal Medicine 3, Institute for Clinical Immunology, University of Erlangen-Nuremberg, Krankenhausstrasse 12, 91054 Erlangen, Germany. 2LIMM, Section of Musculoskeletal Disease, University of Leeds, Chapel Allerton Hospital, Leeds LS9 7TF, UK. ${ }^{3}$ Section of Musculoskeletal Disease, Leeds Institute of Molecular Medicine, University of Leeds, Leeds LS9 7TF, UK. ${ }^{4}$ Section of Musculoskeletal Disease, University of Leeds, and NIHR Leeds Musculoskeletal Biomedical Research Unit, Leeds LS9 7TF, UK.

Published: 25 May 2010

\section{References}

1. Baker WM: The formation of abnormal synovial cysts in the connection with the joints. St Bartholomew's Hospital Reports 1855, 21:177-190.

2. Genovese GR, Jayson MI, Dixon AS: Protective value of synovial cysts in rheumatoid knees. Ann Rheum Dis 1972, 31:179-182.

3. Visser H, le Cessie S, Vos K, Breedveld FC, Hazes JM: How to diagnose rheumatoid arthritis early: a prediction model for persistent (erosive) arthritis. Arthritis Rheum 2002, 46:357-365.

4. Machold KP, Stamm TA, Nell VP, Pflugbeil S, Aletaha D, Steiner G, Uffmann M, Smolen JS: Very recent onset rheumatoid arthritis: clinical and serological patient characteristics associated with radiographic progression over the first years of disease. Rheumatology (Oxford) 2007, 46:342-349.

5. van Gaalen FA, Linn-Rasker SP, van Venrooij WJ, de Jong BA, Breedveld FC, Verweij CL, Toes RE, Huizinga TW: Autoantibodies to cyclic citrullinated peptides predict progression to rheumatoid arthritis in patients with undifferentiated arthritis: a prospective cohort study. Arthritis Rheum 2004 50:709-715.

6. Halvorsen EH, Haavardsholm EA, Pollmann S, Boonen A, van der Heijde D, Kvien TK, Molberg Ø: Serum IgG antibodies to peptidylarginine deiminase 4 predict radiographic progression in patients with rheumatoid arthritis treated with tumour necrosis factor-alpha blocking agents. Ann Rheum Dis 2009, 68:249-252.

7. McInnes I, Schett G: Cytokines in the pathogenesis of rheumatoid arthritis. Nat Immunol 2007, 7:429-442.

8. Van der Heijde DM: Joint erosions and patients with early rheumatoid arthritis. Br J Rheumatol 1995, 34:74-78. 
9. Scott DL, Pugner K, Kaarela K, Doyle DV, Woolf A, Holmes J, Hieke K: The links between joint damage and disability in rheumatoid arthritis. Rheumatology (Oxford) 2000, 39:122-132.

10. Welsing PM, van Gestel AM, Swinkels HL, Kiemeney LA, van Riel PL: The relationship between disease activity, joint destruction, and functional capacity over the course of rheumatoid arthritis. Arthritis Rheum 2001, 44:2009-2017.

11. Aletaha D, Smolen J, Ward MM: Measuring function in rheumatoid arthritis: identifying reversible and irreversible components. Arthritis Rheum 2006, 54:2784-2792

12. Rich E, Moreland LW, Alarcón GS: Paucity of radiographic progression in rheumatoid arthritis treated with methotrexate as the first disease modifying antirheumatic drug. J Rheumatol 1999, 26:259-261.

13. Pullar T, Hunter JA, Capell HA: Effect of sulphasalazine on the radiological progression of rheumatoid arthritis. Ann Rheum Dis 1987, 46:398-402.

14. Möttönen T, Hannonen P, Leirisalo-Repo M, Nissilä M, Kautiainen H, Korpela $\mathrm{M}$ : Comparison of combination therapy with single-drug therapy in early rheumatoid arthritis: a randomised trial. FIN-RACo trial group. Lancet 1999, 353:1568-1573.

15. Boers M, Verhoeven AC, Markusse HM, Van Der Laar MA, Westhovens R, Van Denderen JC: Randomised comparison of combined step-down prednisolone, methotrexate and sulphasalazine with sulphasalazine alone in early rheumatoid arthritis. Lancet 1997, 350:309-318.

16. Smolen JS, Han C, Bala M; ATTRACT Study Group: Evidence of radiographic benefit of treatment with infliximab plus methotrexate in rheumatoid arthritis patients who had no clinical response. Arthritis Rheum 2005, 52:1020-1030

17. Smolen JS, Van Der Heijde DM, St Clair EW, Emery P, Bathon JM, Keystone E: Predictors of joint damage in patients with early rheumatoid arthritis treated with high-dose methotrexate with or without concomitant infliximab: results from the ASPIRE trial. Arthritis Rheum 2006, 54:702-710.

18. Bathon JM, Martin RW, Fleischmann RM: A comparison of etanercept and methotrexate in patients with early rheumatoid arthritis. N Engl J Med 2000, 343:1586-1593.

19. Klareskog L, van der Heijde D, de Jager JP, Gough A, Kalden J, Malaise M: Therapeutic effect of the combination of etanercept and methotrexate compared with each treatment alone in patients with rheumatoid arthritis: double-blind randomised controlled trial. Lancet 2004, 363:675-681.

20. Kekow J, Moots RJ, Emery P, Durez P, Koenig A, Singh A, Pedersen R, Robertson D, Freundlich B, Sato R: Patient-reported outcomes improve with etanercept plus methotrexate in active early rheumatoid arthritis and the improvement is strongly associated with remission: the COMET trial. Ann Rheum Dis 2010, 69:222-225.

21. Breedveld FC, Weisman MH, Kavanaugh AF, Cohen SB, Pavelka K, van Vollenhoven R, Sharp J, Perez JL, Spencer-Green GT: The PREMIER study: a multicenter, randomized, double-blind clinical trial of combination therapy with adalimumab plus methotrexate versus methotrexate alone or adalimumab alone in patients with early, aggressive rheumatoid arthritis who had not had previous methotrexate treatment. Arthritis Rheum 2006, 54:26-37.

22. Keystone EC, Kavanaugh AF, Sharp JT, Tannenbaum H, Hua Y, Teoh LS, Fischkoff SA, Chartash EK: Radiographic, clinical and functional outcomes of treatment with adalimumab (a human anti-tumor necrosis factor monoclonal antibody) in patients with active rheumatoid arthritis receiving concomitant methotrexate therapy: a randomized placebocontrolled 52-week trial. Arthritis Rheum 2004, 50:1400-1411.

23. Kremer J, Ritchlin C, Mendelsohn A, Baker D, Kim L, Xu Z, Han J, Taylor P: Golimumab, a new human anti-tumor necrosis factor antibody, administered intravenously in patients with active rheumatoid arthritis: 48-week efficacy and safety results of a phase III randomized, doubleblind, placebo-controlled study. Arthritis Rheum 2010, 62:917-928.

24. Keystone E, van der Heijde D, Mason D, Jr, Landewe R, van Vollenhoven R, Combe B, Emery P, Strand V, Mease P, Desai C, Pavelka K: Certolizumab pegol plus methotrexate is significantly more effective than placebo plus methotrexate in active rheumatoid arthritis findings of a 52-week, phase III, multicenter, randomized, double-blind, placebo-controlled, parallelgroup study [RAPID1]. Arthritis Rheum 2008, 58:3319-3329.

25. Lam J, Takeshita S, Barker JE, Kanagawa O, Ross FP, Teitelbaum SL: TNF-a induces osteoclastogenesis by direct stimulation of macrophages exposed to permissive levels of RANK ligand. J Clin Invest 2000,
106:1481-1488.

26. Keffer J, Probert L, Cazlaris H, Georgopoulos S, Kaslaris E, Kioussis D, Kollias G: Transgenic mice expressing human tumour necrosis factor: a predictive genetic model of arthritis. EMBO J 1991, 10:4025-4031.

27. Schett G, Redlich K, Hayer S, Zwerina J, Bolon B, Dunstan C, Görtz B, Schulz A, Bergmeister H, Kollias G, Steiner G, Smolen JS: Osteoprotegerin protects against generalized bone loss in tumor necrosis factor-transgenic mice. Arthritis Rheum 2003, 48:2042-2051.

28. Tiderius CJ, Sandin J, Svensson J, Dahlberg LE, Jacobsson L: Knee cartilage quality assessed with dGEMRIC in rheumatoid arthritis patients before and after treatment with a TNF inhibitor. Acta Radiol 2010, 51:1034-1037.

29. Lukas C, van der Heijde D, Fatenejad S, Landewé R: Repair of erosions occurs almost exclusively in damaged joints without swelling. Ann Rheum Dis 2010, 69:851-855.

30. Møller Døhn U, Boonen A, Hetland ML, Hansen MS, Knudsen LS, Hansen A, Madsen OR, Hasselquist M, Møller JM, Østergaard M: Erosive progression is minimal, but erosion healing rare, in patients with rheumatoid arthritis treated with adalimumab. A 1-year investigator-initiated follow-up study using high-resolution computed tomography as the primary outcome measure. Ann Rheum Dis 2009, 68:1585-1590.

31. Van Der Kooij SM, Goekoop-Ruiterman YPM, De Vries-Bouwstra JK, GulerYuksel M, Zwinderman AH, Kerstens PJSM, Van Der Lubbe PAHM, De Beus WM, Grillet BAM, Ronday K, Huizinga TWJ, Breedveld FC, Dijkmans BAC, Allaart CF: Drug-free remission, functioning, and radiographic damage after 4 years of response-driven treatment in patients with recent onset rheumatoid arthritis [BeSt trial]. Ann Rheum Disease 2009, 68:914-921.

32. Cohen G, Gossec L, Dougados M, Cantagrel A, Goupille P, Daures JP, Rincheval $\mathrm{N}$, Combe B: Radiological damage in patients with rheumatoid arthritis on sustained remission. Ann Rheum Dis 2007, 66:358-363.

33. Molenaar ET, Voskuyl AE, Dinant HJ, Bezemer PD, Boers M, Dijkmans BA: Progression of radiologic damage in patients with rheumatoid arthritis in clinical remission. Arthritis Rheum 2004, 50:36-42.

34. Bruyn GA, Pineda C, Hernandez-Diaz C, Ventura-Rios L, Moya C, Garrido f, Groen H, Pena A, Espinosa R, Möller I, Filippucci E, lagnocco A, Balint PV, Kane D, D'Agostino MA, Angulo M, Ponte R, Fernandez-Gallardo JM, Naredo E: Validity of ultrasonography and measures of adult shoulder function and reliability of ultrasonography in detecting shoulder synovitis in patients with rheumatoid arthritis using magnetic resonance imaging as a gold standard. Arthritis Care Res (Hoboken) 2010, 62:1079-1086.

35. Kraan MC, Versendaal H, Jonker M, Bresnihan B, Post WJ, t Hart BA, Breedveld FC, Tak PP: Asymptomatic synovitis precedes clinically manifest arthritis. Arthritis Rheum 1998, 41:1481-1488.

36. Østergaard M, Pedersen SJ, Døhn UM: Imaging in rheumatoid arthritis status and recent advances for magnetic resonance imaging, ultrasonography, computed tomography and conventional radiography. Best Pract Res Clin Rheumatol 2008, 22:1019-1044.

37. Salimi C, O'Neill J, Khalidi N, Harish S: Role of ultrasound in the assessment of small-joint synovitis. Can Assoc Radiol J 2009, 60:69-70.

38. Cyteval C: Doppler ultrasonography and dynamic magnetic resonance imaging for assessment of synovitis in the hand and wrist of patients with rheumatoid arthritis. Semin Musculoskelet Radiol 2009, 13:66-73.

39. Moll JM, Wright V: Psoriatic arthritis. Semin Arth Rheum 1973, 3:55-78.

40. Taylor W, Gladman D, Helliwell P, Marchesoni A, Mease P, Mielants H: Classification criteria for psoriatic arthritis: development of new criteria from a large international study [CASPAR]. Arthritis Rheum 2006, 54:2665-2673

41. Finzel S, Englbrecht M, Engelke K, Stach C, Schett G: A comparative study of periarticular bone lesions in rheumatoid arthritis and psoriatic arthritis. Ann Rheum Dis 2011, 70:122-127.

42. Sokoll KB, Helliwell PS: Comparison of disability and quality of life in rheumatoid and psoriatic arthritis. J Rheumatol 2001, 28:1842-1846.

43. Gladman DD, Stafford-Brady F, Chang CH, Lewandowski K, Russell ML: Longitudinal study of clinical and radiological progression in psoriatic arthritis. J Rheumatol 1990, 17:809-812.

44. Gladman DD, Farewell VT, Nadeau C: Clinical indicators of progression in psoriatic arthritis: multivariate relative risk model. J Rheumatol 1995 , 22:675-679.

45. Queiro-Silva R, Torre-Alonso JC, Tinture-Eguren T, Lopez-Lagunas I: A polyarticular onset predicts erosive and deforming disease in psoriatic arthritis. Ann Rheum Dis 2003, 62:68-70

46. Gladman DD, Farewell VT: Progression in psoriatic arthritis: role of time 
varying clinical indicators. J Rheumatol 1999, 26:2409-2413.

47. Taccari E, Spadaro A, Riccieri V: Correlations between peripheral and axial radiological changes in patients with psoriatic polyarthritis. Rev Rheum (Engl) 1996, 63:17-23.

48. Mader R, Gladman DD, Long J, Gough J, Farewell VT: Does injectable gold retard radiologic evidence of joint damage in psoriatic arthritis? Clin Invest Med 1995, 18:139-143.

49. Rahman P, Gladman DD, Cook RJ, Zhou Y, Young G: The use of sulfasalazine in psoriatic arthritis: a clinic experience. J Rheumatol 1998, 25:1957-1961.

50. Abu-Shakra M, Gladman DD, Thorne JC, Long J, Gough J, Farewell VT: Longterm methotrexate therapy in psoriatic arthritis: clinical and radiological outcome. J Rheumatol 1995, 22:241-245.

51. Chandran V, Schentag CT, Gladman DD: Reappraisal of the effectiveness of methotrexate in psoriatic arthritis: results from a longitudinal observational cohort. J Rheumatol 2008, 35:469-471.

52. Kavanaugh A, Antoni CE, Gladman D, Wassenberg S, Zhou B, Beutler A: The Infliximab Multinational Psoriatic Arthritis Controlled Trial (IMPACT): results of radiographic analyses after 1 year. Ann Rheum Dis 2006, 65:1038-1043

53. Kavanaugh A, Krueger GG, Beutler A, Guzzo C, Zhou B, Dooley LT, Mease PJ, Gladman DD, de Vlam K, Geusens PP, Birbara C, Halter DG, Antoni C; IMPACT 2 Study Group: Infliximab maintains a high degree of clinical response in patients with active psoriatic arthritis through 1 year of treatment: results from the IMPACT 2 trial. Ann Rheum Dis 2007, 66:498-505.

54. Mease PJ, Gladman DD, Ritchlin CT, Ruderman EM, Steinfeld SD, Choy EH: Adalimumab for the treatment of patients with moderately to severely active psoriatic arthritis: results of a double-blind, randomized, placebocontrolled trial. Arthritis Rheum 2005, 52:3279-3289.

55. Mease PJ, Kivitz AJ, Burch FX, Siegel EL, Cohen SB, Ory P: Continued inhibition of radiographic progression in patients with psoriatic arthritis following 2 years of treatment with etanercept. J Rheumatol 2006, 33:712-721

56. van der Heijde D, Kavanaugh A, Gladman DD, Antoni C, Krueger GG, Guzzo C: Infliximab inhibits progression of radiographic damage in patients with active psoriatic arthritis through one year of treatment: results from the induction and maintenance psoriatic arthritis clinical trial 2. Arthritis Rheum 2007, 56:2698-2707.

57. Gladman DD, Mease PJ, Choy EHS, Ritchlin CT, Perdok RJ, Sasso EH: Risk factors for radiographic progression in psoriatic arthritis: subanalysis of the randomized controlled trial ADEPT. Arthritis Res Ther 2010, 12:R113.

58. Mease PJ, Kivitz AJ, Burch FX, Siegel EL, Cohen SB, Ory P: Etanercept treatment of psoriatic arthritis: safety, efficacy, and effect on disease progression. Arth Rheum 2004, 50:2264-2272.

59. Antoni CE, Kavanaugh A, Kirkham B, Tutuncu Z, Burmester GR, Schneider U: Sustained benefits of infliximab therapy for dermatologic and articular manifestations of psoriatic arthritis: results from the infliximab multinational psoriatic arthritis controlled trial (IMPACT). Arthritis Rheum 2005, 52:1227-1236; erratum Arthritis Rheum 2005, 52:2951.

60. Antoni C, Krueger GG, de Vlam K, Birbara C, Beutler A, Guzzo C: Infliximab improves signs and symptoms of psoriatic arthritis: results of the IMPACT 2 trial. Ann Rheum Dis 2005, 64:1150-1157.

61. Mease PJ, Goffe BS, Metz J, VanderStoep A, Finck B, Burge DJ: Etanercept in the treatment of psoriatic arthritis and psoriasis: a randomised trial. Lancet 2000, 356:385-390

62. Kavanaugh A, McInnes I, Mease P: Golimumab, a new human tumor necrosis factor a antibody, administered every four weeks as a subcutaneous injection in psoriatic arthritis: twenty-four-week efficacy and safety results of a randomized, placebo-controlled study. Arthritis Rheum 2009, 60:976-986.

63. Brown AK, Quinn MA, Karim Z, Conaghan PG, Peterfy CG, Hensor E: Presence of significant synovitis in rheumatoid arthritis patients with diseasemodifying antirheumatic drug-induced clinical remission: evidence from an imaging study may explain structural progression. Arthritis Rheum 2006, 54:3761-3773.

64. McQueen FM, Benton N, Perry D, Crabbe J, Robinson E, Yeoman S: Bone edema scored on magnetic resonance imaging scans of the dominant carpus at presentation predicts radiographic joint damage of the hands and feet six years later in patients with rheumatoid arthritis. Arthritis Rheum 2003, 48:1814-1827.

65. Grigor C, Capell H, Stirling A, McMahon AD, Lock P, Vallance R, Kincaid W, Porter D: Effect of a treatment strategy of tight control for rheumatoid arthritis (the TICORA study): a single-blind randomised controlled trial. Lancet 2004, 364:263-269.

66. Bakker MF, Jacobs JWG, Verstappen SMM, Bijlmsa JWJ: Tight control in the treatment of rheumatoid arthritis: efficacy and feasibility. Ann Rheum Dis 2007, 66(Suppl III):iii56-iii60.

67. Coates $L C$, Fransen J, Helliwell PS: Defining minimal disease activity in psoriatic arthritis: a proposed target for treatment. Ann Rheum Dis 2010, 69:48-53.

68. Marzo-Ortega H, McGonagle D, O'Connor P, Hensor EM, Bennett AN, Green MJ: Baseline and 1-year magnetic resonance imaging of the sacroiliac joint and lumbar spine in very early inflammatory back pain. Relationship between symptoms, HLA-B27 and disease extent and persistence. Ann Rheum Dis 2009, 68:1721-1727.

69. van der Linden S, Valkenburg HA, Cats A: Evaluation of diagnostic criteria for ankylosing spondylitis. A proposal for modification of the New York criteria. Arth Rheum 1984, 27:361-368.

70. Mau W, Zeidler H, Mau R, Majewski A, Freyschmidt J, Stangel W: Clinical features and prognosis of patients with possible ankylosing spondylitis. Results of a 10-year followup. J Rheumatol 1988, 15:1109-1114.

71. Rudwaleit M, Khan MA, Sieper J: The challenge of diagnosis and classification in early ankylosing spondylitis: do we need new criteria? Arthritis Rheum 2005, 52:1000-1008.

72. Rudwaleit M, Haibel H, Baraliakos X, Listing J, Märker-Hermann E, Zeidler H, Braun J, Sieper J: The early disease stage in axial spondylarthritis: results from the German Spondyloarthritis Inception Cohort. Arthritis Rheum 2009, 60:717-727.

73. Rudwaleit M, Listing J, Brandt J, Braun J, Sieper J: Prediction of a major clinical response (BASDAI 50) to tumour necrosis factor alpha blockers in ankylosing spondylitis. Ann Rheum Dis 2004, 63:665-670.

74. Creemers MC, Franssen MJ, van't Hof MA, Gribnau FW, van de Putte LB, van Riel PL: Assessment of outcome in ankylosing spondylitis: an extended radiographic scoring system. Ann Rheum Dis 2005, 64:127-129.

75. Braun J, Baraliakos X, Golder W, Hermann KG, Listing J, Brandt J: Analysing chronic spinal changes in ankylosing spondylitis: a systematic comparison of conventional $X$ rays with magnetic resonance imaging using established and new scoring systems. Ann Rheum Dis 2004, 63:1046-1055.

76. Baraliakos X, Hermann KG, Landewe R, Listing J, Golder W, Brandt J: Assessment of acute spinal inflammation in patients with ankylosing spondylitis by magnetic resonance imaging: a comparison between contrast enhanced T1 and short tau inversion recovery (STIR) sequences. Ann Rheum Dis 2005, 64:1141-1144.

77. Spoorenberg A, de Vlam K, van der Linden S, Dougados M, Mielants $\mathrm{H}$, van de Tempel H: Radiological scoring methods in ankylosing spondylitis. Reliability and change over 1 and 2 years. J Rheumatol 2004, 31:125-132.

78. Wanders A, Heijde D, Landewe R, Behier JM, Calin A, Olivieri I: Nonsteroidal antiinflammatory drugs reduce radiographic progression in patients with ankylosing spondylitis: a randomized clinical trial. Arthritis Rheum 2005, 52:1756-1765.

79. National Institute for Health and Clinical Excellence: Adalimumab, Etanercept and Infliximab for Ankylosing Spondylitis. London: NICE; 2008.

80. Zochling J, van der Heijde D, Burgos-Vargas R, Collantes E, Davis JC, Jr, Dijkmans B: ASAS/EULAR recommendations for the management of ankylosing spondylitis. Ann Rheum Dis 2006, 65:442-452.

81. Baraliakos X, Listing J, Brandt J, Zink A, Alten R, Burmester G: Clinical response to discontinuation of anti-TNF therapy in patients with ankylosing spondylitis after 3 years of continuous treatment with infliximab. Arthritis Res Ther 2005, 7:R439-R444.

82. Brandt J, Listing J, Haibel H, Sorensen H, Schwebig A, Rudwaleit M: Longterm efficacy and safety of etanercept after readministration in patients with active ankylosing spondylitis. Rheumatology (Oxford) 2005, 44:342-348.

83. van der Heijde $D$, Landewe $R$, Baraliakos $X$, Houben $H$, van Tubergen $A$, Williamson P: Radiographic findings following two years of infliximab therapy in patients with ankylosing spondylitis. Arth Rheum 2008, 58:3063-3070.

84. van der Heijde D, Landewe R, Einstein S, Ory P, Vosse D, Ni L: Radiographic progression of ankylosing spondylitis after up to two years of treatment with etanercept. Arthritis Rheum 2008, 58:1324-1331.

85. van der Heijde D, Salonen D, Weissman BN, Landewe R, Maksymowych WP, Kupper H: Assessment of radiographic progression in the spines of patients with ankylosing spondylitis treated with adalimumab for up to 2 years. Arthritis Res Ther 2009, 11:R127. 
86. Baraliakos X, Listing J, Rudwaleit M, Brandt J, Sieper J, Braun J: Radiographic progression in patients with ankylosing spondylitis after 2 years of treatment with the tumour necrosis factor alpha antibody infliximab. Ann Rheum Dis 2005, 64:1462-1466.

87. Baraliakos X, Listing J, Brandt J, Haibel H, Rudwaleit M, Sieper J. Radiographic progression in patients with ankylosing spondylitis after 4 yrs of treatment with the anti-TNF-alpha antibody infliximab. Rheumatology (Oxford) 2007, 46:1450-1453.

88. Baraliakos X, Listing J, Rudwaleit M, Haibel H, Brandt J, Sieper J: Progression of radiographic damage in patients with ankylosing spondylitis: defining the central role of syndesmophytes. Ann Rheum Dis 2007, 66:910-915.

89. Bennett AN, McGonagle D, O'Connor P, Hensor EM, Sivera F, Coates LC: Severity of baseline magnetic resonance imaging-evident sacroiliitis and HLA-B27 status in early inflammatory back pain predict radiographically evident ankylosing spondylitis at eight years. Arthritis Rheum 2008, 58:3413-3418

90. Rudwaleit M, van der Heijde D, Landewe R, Listing J, Akkoc N, Brandt J: The development of Assessment of SpondyloArthritis international Society classification criteria for axial spondyloarthritis (part II): validation and final selection. Ann Rheum Dis 2009, 68:777-783.

91. Maksymowych WP, Chiowchanwisawakit P, Clare T, Pedersen SJ, Ostergaard M, Lambert RG: Inflammatory lesions of the spine on magnetic resonance imaging predict the development of new syndesmophytes in ankylosing spondylitis: evidence of a relationship between inflammation and new bone formation. Arthritis Rheum 2009, 60:93-102

92. Diarra D, Stolina M, Polzer K, Zwerina J, Ominsky MS, Dwyer D: Dickkopf-1 is a master regulator of joint remodeling. Nat Med 2007, 13:156-163.

93. Lories RJ, Derese I, de Bari C, Luyten FP: Evidence for uncoupling of inflammation and joint remodeling in a mouse model of spondylarthritis. Arthritis Rheum 2007, 56:489-497.

94. Baraliakos X, Listing J, Rudwaleit M, Sieper J, Braun J: The relationship between inflammation and new bone formation in patients with ankylosing spondylitis. Arthritis Res Ther 2008, 10:R104.

95. Bennett AN, Rehman A, Hensor EM, Marzo-Ortega H, Emery P, McGonagle DG: The fatty Romanus lesion: a non-inflammatory spinal MRI lesion specific for axial-spondyloarthropathy. Ann Rheum Dis 2010, 69:891-894.

96. Braun J, Baraliakos X, Brandt J, Listing J, Zink A, Alten R: Persistent clinical response to the anti-TNF- $\alpha$ antibody infliximab in patients with ankylosing spondylitis over 3 years. Rheumatology (Oxford) 2005, 44:670-676.

97. Braun J, Baraliakos X, Listing J, Fritz C, Alten R, Burmester G: Persistent clinical efficacy and safety of anti-tumour necrosis factor alpha therapy with infliximab in patients with ankylosing spondylitis over 5 years: evidence for different types of response. Ann Rheum Dis 2008, 67:340-345.

98. Braun J, Brandt J, Listing J, Zink A, Alten R, Burmester G: Long-term efficacy and safety of infliximab in the treatment of ankylosing spondylitis: an open, observational, extension study of a three-month, randomized, placebo-controlled trial. Arthritis Rheum 2003, 48:2224-2233.
99. Braun J, Brandt J, Listing J, Zink A, Alten R, Burmester G: Two year maintenance of efficacy and safety of infliximab in the treatment of ankylosing spondylitis. Ann Rheum Dis 2005, 64:229-234.

100. Braun J, Brandt J, Listing J, Zink A, Alten R, Golder W: Treatment of active ankylosing spondylitis with infliximab: a randomised controlled multicentre trial. Lancet 2002, 359:1187-1193.

101. Marzo-Ortega H, McGonagle D, Jarrett S, Haugeberg G, Hensor E, O'Connor P: Infliximab in combination with methotrexate in active ankylosing spondylitis: a clinical and imaging study. Ann Rheum Dis 2005, 64:1568-1575

102. van der Heijde D, Dijkmans B, Geusens P, Sieper J, DeWoody K, Williamson P: Efficacy and safety of infliximab in patients with ankylosing spondylitis: results of a randomized, placebo-controlled trial (ASSERT). Arth Rheum 2005, 52:582-591.

103. Davis JC, Jr, Van Der Heijde D, Braun J, Dougados M, Cush J, Clegg DO: Recombinant human tumor necrosis factor receptor (etanercept) for treating ankylosing spondylitis: a randomized, controlled trial. Arthritis Rheum 2003, 48:3230-3236.

104. Davis JC, Jr, van der Heijde DM, Braun J, Dougados M, Clegg DO, Kivitz AJ: Efficacy and safety of up to 192 weeks of etanercept therapy in patients with ankylosing spondylitis. Ann Rheum Dis 2008, 67:346-352.

105. Davis JC, van der Heijde DM, Braun J, Dougados M, Cush J, Clegg D: Sustained durability and tolerability of etanercept in ankylosing spondylitis for 96 weeks. Ann Rheum Dis 2005, 64:1557-1562.

106. Calin A, Dijkmans BA, Emery P, Hakala M, Kalden J, Leirisalo-Repo M: Outcomes of a multicentre randomised clinical trial of etanercept to treat ankylosing spondylitis. Ann Rheum Dis 2004, 63:1594-1600.

107. Dijkmans B, Emery P, Hakala M, Leirisalo-Repo M, Mola EM, Paolozzi L: Etanercept in the longterm treatment of patients with ankylosing spondylitis. J Rheumatol 2009, 36:1256-1264.

108. van der Heijde D, Kivitz A, Schiff MH, Sieper J, Dijkmans BA, Braun J: Efficacy and safety of adalimumab in patients with ankylosing spondylitis: results of a multicenter, randomized, double-blind, placebo-controlled trial. Arthritis Rheum 2006, 54:2136-2146.

109. Inman RD, Davis JC, Jr, Heijde D, Diekman L, Sieper J, Kim SI: Efficacy and safety of golimumab in patients with ankylosing spondylitis: results of a randomized, double-blind, placebo-controlled, phase III trial. Arthritis Rheum 2008, 58:3402-3412.

doi:10.1186/ar3095

Cite this article as: Schett G, et al:: Structural damage in rheumatoid arthritis, psoriatic arthritis, and ankylosing spondylitis: traditional views, novel insights gained from TNF blockade, and concepts for the future. Arthritis Research \& Therapy 2011, 13(Suppl 1):S4. 